\title{
IN VITRO PRODUCTION OF BANANA PLANTLETS AND THEIR VALIDATION AT HILL VALLEYS
}

\author{
M.M.H. Molla ${ }^{1 *}$, D. Khanam ${ }^{1}$, Z.A. Firoz ${ }^{2}$, S.P. Chakma ${ }^{3}$ \\ S.C. Halder ${ }^{1}$ and M.A. Salam ${ }^{4}$ \\ ${ }^{1}$ Biotechnology Division, Bangladesh Agricultural Research Institute, Gazipur-1701 \\ ${ }^{2}$ Agricultural Research Station, Ramgarh, Bangladesh \\ ${ }^{3}$ Agricultural Research Station, Raikhali, Bangladesh \\ ${ }^{4}$ Bangladesh Agricultural Research Council, Farmgate, Dhaka-1215
}

\begin{abstract}
Performances of tissue cultured (TC) plantlets of BARI Kola-3 and BARI Kola-4 were evaluated against transplanting of conventional (CON) sucker at hill valleys during July 2011 to December 2014. The plantlets were produced at Biotech Lab, BARI Gazipur and validation trial was conducted at Ramgarh, Khagrachari hill district during March-April and September-October planting seasons (2011-14). Murashige and Skoog (MS) basal medium supplemented @ $3 \mathrm{mg}^{-1}$ and $5 \mathrm{mg} \mathrm{l}^{-1}$ BAP showed the best performance for multiple shoot production in BARI Kola-3 and BARI Kola-4, respectively. Both the varieties produced well developed roots in $1 / 2 \mathrm{MS}$ medium supplemented @ $0.5 \mathrm{mg}^{-1}$ IBA. Among the plantlets $98.5 \%$ plantlets were survived when hardened 7 days under polyethylene tunnel after 5 days hardening at room temperature but $100 \%$ plantlets died when transplanted plantlets were kept in open conditions at the nursery. 45 day - old healthy plantlets were planted at hill valleys in September-October and April-May planting seasons. BARI Kola-3 produced the highest 45.67 and $44.05 \mathrm{t} \mathrm{ha}^{-1}$ bunch yield at AprilMay and September-October planting, respectively. The highest $55.89 \mathrm{t}$ ha $^{-1}$ bunch yield was recorded from TC BARI Kola-4 in March-April planting followed by $49.67 \mathrm{t} \mathrm{ha}^{-1}$ in September-October Planting. TC BARI Kola-3 and BARI Kola-4 produced 3.68 and $12.52 \%$ higher yields in March-April planting, respectively than September-October planting. In case of planting materials, TC BARI Kola-3 and TC BARI Kola-4 produced 23.43 and $20.33 \%$ higher yield over CON suckered plant in March-April planting. On the other hand, TC BARI Kola-3 and TC BARI Kola-4 also produced 12.34 and $9.35 \%$ higher yield than CON Suckered plant in September-October planting. Similarly, TC BARI Kola-4 produced $28.33 \%$ higher yield than CON suckered BARI Kola-4 in March-April planting. In every case, TC plants showed better performances than the CON suckered plant.
\end{abstract}

\footnotetext{
*Correspondence author: mhmolla@ hotmail.com
}

Received: 28.12.2016 
Keywords: Banana, tissue culture, phytohormones, planting season, yield

\section{INTRODUCTION}

Banana (Musa sp.) is the most important fruit crop in Bangladesh. It grows all over the country but production is mainly concentrated in the Chittagong hill tract regions. Recently, commercial cultivation has been started at North-Western part of the country. In Bangladesh, area under banana cultivation is 47 thousand hectares of land and production is 0.77 million metric tons in a year (BBS, 2013-14). The average yield of banana is $16.62 \mathrm{t} \mathrm{ha}^{-1}$ which is much lower than that of other banana growing countries. Bananas are propagated vegetatively by means of sucker which is very slow process. In this way, each plant produced small number sword suckers in a year which is a great limitation for commercial cultivation and this material carries the most devastating disease (Rahman et al., 2002). Such problems further aggravates by common practice of propagation using infected suckers. BARI Kola-3 and BARI Kola-4 are popular high yielding varieties and widely cultivated all over the country. These two varieties are also suitable for hilly regions (Saha, 2010). Although hill valleys are important for banana cultivation but unfortunately, commercial cultivation of BARI Kola-3 and BARI Kola-4 is absent at hilly areas. Hilly peoples grows banana along with zoom, homestead and at the foot of the hills scattered (Uddin et al., 1998). Due to the lack of quality sucker, post harvest processing and transportation system, farmers cannot cultivate banana commercially at hilly areas (Annon, 2010). Tissue culture method can produce a huge amount of disease free banana plantlets in limited time and space (Molla et al., 2004). These plantlets are genetically homogeneous; more than $95 \%$ of total products are at a time harvestable with 10-15\% higher yield (Akhond and Bhuiyan, 2001). Moreover, this planting material resists bunchy top disease for several ratoon crops with higher yield (Khanam et al., 2014). Biotechnology division, BARI has been developed a protocol for multiplication of Amrithsagar and BARI Kola-1 (Khatun et al., 2003). Usually this protocol varies variety to variety. So far it was reviewed; the protocol for BARI Kola-3 and BARI Kola-4 was not optimized. So, the existing protocol was needed to optimize. Research report on tissue culture banana plantlet cultivation at hilly areas of Bangladesh is not published yet. This is so far the first research report on tissue culture banana plantlet cultivation at hilly areas in Bangladesh. Therefore, the study was conducted to optimize the existing protocol for in vitro production of BARI Kola-3 and BARI Kola-4 and validate the performance of tissue cultured banana plantlets at hill valleys. 


\section{MATERIALS AND METHODS}

Sword sucker of BARI Kola-3 and BARI Kola-4 from disease-free plant were collected from Agricultural Research Station (ARS), Raikhali, Rangamati from mother orchard. Roots and outer layer of tissues of the suckers were removed and the remaining portions were washed with tap water with detergent. The explants were then surface sterilized in 60\% Clorox with a few drops of Tween-20 for $30 \mathrm{~min}$. After washing 4 times with sterilized distilled water, the shoot tips were further cut to a size of approximately $1.0 \mathrm{~cm}$ portion containing an intact apex under clean bench. The explants were placed on MS medium (Murashige and Skoog, 1962) supplemented with different concentrations of cytokinins (BAP and 2-ip) for in vitro multiple shoot production. All cultures were incubated at $25 \pm 1^{\circ} \mathrm{C}$ with a $16 \mathrm{hrs}$ photoperiod provided by cool white florescent tubes. The $\mathrm{pH}$ of the medium was adjusted to 5.8 prior to autoclaving. The materials were sub-cultured at 30 day's interval in the same medium to produce multiple shoots. Well developed shoots were transferred to rooting medium containing $1 / 2 \mathrm{MS}$ medium supplemented with different concentrations of IBA for root induction. At the age of 28 days in rooting medium, well developed rooted plantlets were kept at room temperature for 5 days and then transferred to poly bags containing soil, sand and decomposed cow dung (1:1:1). Transplanted plantlets were hardened under polyethylene tunnel for 7 days and then shifted at nursery conditions for growth and development. After 45 days, well established plantlets were transplanted for validation. Plantlets were planted $2.0 \mathrm{~m} \times 2.0 \mathrm{~m}$ spacing with factorial RCB design having 3 replications during March-April and September-October planting season along with traditional sucker. Before planting, randomly 100 sample plantlets were tested for bunchy top virus using Agdia Bunchy top virus testing kit (USA). Data on plant height $(\mathrm{cm})$, base girth $(\mathrm{cm})$, number of leaves at flowering, days to $50 \%$ flowering, days to harvest, no. of finger per bunch, no. of hands per bunch, wt. of individual finger (g.), individual bunch wt. (kg) and yield $\left(\mathrm{t} \mathrm{ha}^{-1}\right)$ etc. were recorded and data were analyzed using Mstat-C statistical package. Differences among the means were compared by the Duncan's Multiple Range Test at 1\% level of significance (Gomez and Gomez, 1984).

\section{RESULTS AND DISCUSSIONS}

\section{Standardization of protocol for in vitro production of BARI Kola-3 and BARI Kola-4}

The study was conducted to find out an efficient dose of cytokinin (BAP and 2ip) for in vitro production of BARI Kola-3 and BARI Kola-4. Shoot tip of BARI Kola-3 and BARI Kola-4 were cultured in MS medium supplemented with six different concentrations of BAP (viz., 1, 2, 3, 4, 5 and $6 \mathrm{mg}^{-1}$ ) and three different concentrations of 2-ip (viz., 1.0, 1.5, 2.0, $2.5 \mathrm{mg} 1^{-1}$ ). BARI Kola-4 produced the highest number of shoots per plant (7.0) in MS medium supplemented with BAP 5.0 $\mathrm{mg} 1^{-1}$ followed by BARI Kola-3 (6.1) in BAP $3.0 \mathrm{mg}^{-1}$ (Figure $1 \&$ Plate 1) within 40.0 and 42.55 days, respectively. 


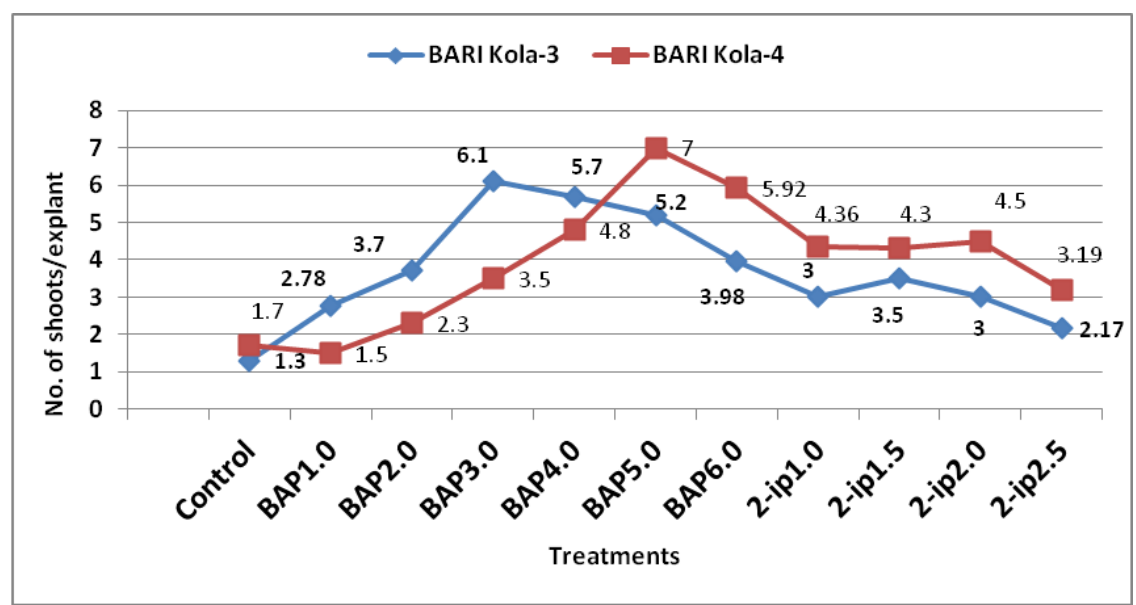

Figure 1. Shoot proliferation and multiple shooting of BARI Kola-3 and BARI kola-4

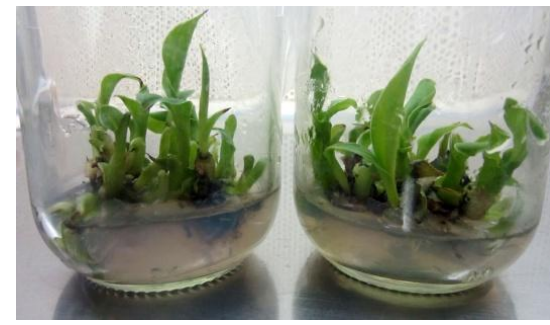

Plate 1.a. Multiple shoots (BARI Kola-3)

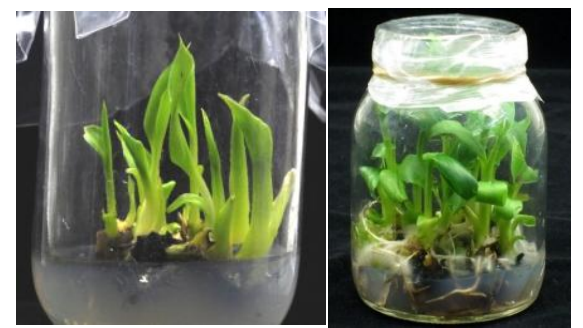

Plate 1.b. Multiple shoots (BARI Kola-4)

Control treatment did not produce any lateral shoots. Cytokinin is generally considered necessary for the acquisition of the meristematic competence of the responsive cells. Once this competence has been established, excessive concentration is often found to be inhibitory for further embryonic or adventitious bud development (Khanam et al., 2007, Molla et al., 2004). However, higher concentration of BAP produced maximum number of shoots up to a certain level where lower concentration induced minimum number of shoots. Cytokinin reduced the callus phase and accelerated shoot regeneration. The findings are accordance with Khatun et al., 2006; Khanam et al., 2007.

\section{Effect of IBA on in vitro rooting at BARI kola-3 and BARI Kola-4}

The study was conducted to find out an efficient dose of IBA for in vitro root production of BARI Kola-3 and BARI Kola-4. After five sub-cultures, well developed shoots were transferred to rooting medium. Half MS medium supplemented with different concentration of $\operatorname{IBA}\left(0.1,0.3,0.5 .0 .7\right.$ and $\left.0.9 \mathrm{mg} 1^{-1}\right)$ were tested for rooting of BARI Kola-3 and BARI Kola-4. Thirty six explants were 
cultured on each treatment where survival percentage was $100 \%$. The maximum 15.6 days required for root induction in BARI Kola-3 only in $1 / 2 \mathrm{MS}$ medium whereas only 4 days was needed to root initiation in BARI Kola-4 in $1 / 2$ MS medium supplemented $0.5 \mathrm{mg} 1^{-1}$ IBA.

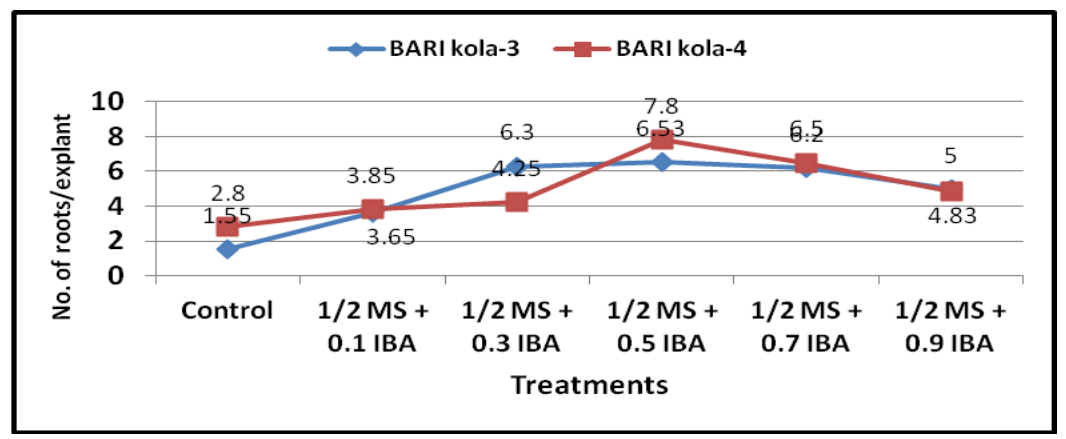

Figure 2. Root induction as influenced by different concentrations of IBA

The maximum number of roots (7.80) was recorded in BARI Kola-4 in 1/2MS medium supplemented with $0.5 \mathrm{mg} 1^{-1}$ IBA followed by BARI Kola-3 (6.53) with same level of IBA (Figure 2, Plate 2).

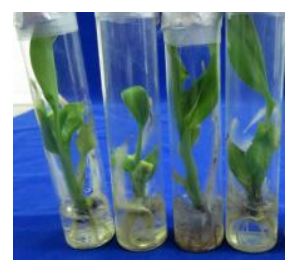

Plate 2.a: Plantlets (BARI Kola-3)

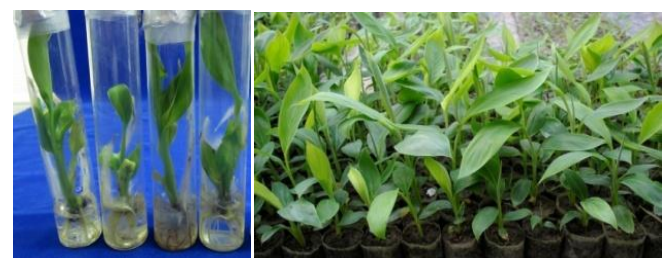

Plate 2.b: Plantlets (BARI Kola-4)

Number of root per plant decreased after a certain levels of IBA in $1 / 2 \mathrm{MS}$ medium. This might be due to excessive dose of hormone. Control treatment produced minimum number of roots which were very lean and thin. Moreover, number of root/plant varied due to growth and development of shoots cultured in rooting medium. Higher dose of IBA in the medium also reduced the number of root/plant. These findings are in accordance with Molla et al., 2004. Auxin is generally necessary for the acquisition of the meristematic competence of the responsive rooting cells. Once this competence has been established, excessive concentration is often found to be inhibitory for further embryonic or adventitious bud development (Khanam et al., 2007). Lower concentration of auxin and cytokinin influenced the formation of both root and shoot but at higher concentrations plantlets showed reversed trends (Sanavy and Moeini, 2003) 
M.M.H. Molla et al.

\section{Ex vitro establishment}

The rooted plantlets with 5 leaves stage were transferred from culture room and kept at room temperature for 5 days. The plantlets were then removed from the culture tubes and all the adhering media were carefully washed out so that, the root damage was the least. Washed plantlets were planted into small polyethylene bags $(24 \mathrm{~cm} \times 16 \mathrm{~cm})$ containing soil, sand and decomposed cow dung at the ratio of 1: 1: 1 . More than $98.5 \%$ in vitro plantlets survived when these plantlets were kept at room temperature for 5 days and hardened inside the polythene tunnel house for 7 days at nursery on moist condition but $100 \%$ plantlets were died where the plantlets were transferred to net house at normal temperature under open condition.

Field performance of TC plantlets against CON sucker at March -April and September-October Planting:

Tissue culture (TC) plantlets of BARI Kola-3 and BARI Kola-4 along with CON sucker were planted at hill valleys during March-April and September-October planting seasons. Details results have been presented in table 1.

There was a significant variation on plant height due to the effect of planting season and propagating materials. The maximum plant height $356.33 \mathrm{~cm}$ was recorded in TC BARI Kola-3 in March-April planting followed by CON suckered BARI Kola-3 $(347 \mathrm{~cm})$. The lowest plant height $(319.67 \mathrm{~cm})$ was recorded in CON suckered BARI Kola-4. The results revealed that TC BARI Kola-3 gave the highest plant height in both seasons compare to TC BARI Kola-4. This might be due to genetic and seasonal effect. Effect of season and propagating materials had significant effect on base girth which ranged from 65.11 to $85.04 \mathrm{~cm}$. The highest base girth $85.04 \mathrm{~cm}$ was recorded in TC BARI Kola-3 in March-April planting followed by TC BARI Kola-3 in September-October. Lowest base girth $(65.11 \mathrm{~cm})$ was recorded in CON suckered BARI Kola-4 in September-October planting (Table 1). This might be due to available soil moisture during March-April planting and residual hormonal effect in TC planting material. Distinct variation was found in respect of number of leaves per plant at harvest due to the season and propagating materials. The maximum number of leaves (23.40) was counted in TC BARI Kola-3 at September-October planting while 22.89 was counted in CON BARI Kola-3. On the other hand, TC BARI Kola-4 produced maximum 22.66 leaves per plant followed by CON suckered (22.21) at the same season (Table 1). In case of March-April planting, maximum number of leaves per plant (22.85) was counted in TC BARI Kola-3 followed by CON suckered plant $(22.61)$ which was statistically similar. There was no significant difference between the number of leaves in TC BARI Kola4 and CON suckered plants (Table 1). Distinct variation was found in respect of days to $50 \%$ flowering due to the season and planting materials (Table 1). Seventeen days early flowering was found at TC BARI Kola-3 than CON suckered plant which was statistically significant. It was needed minimum 375 days for $50 \%$ flowering. However, TC BARI Kola-4 needed 359.33 days for 50\% flowering followed by 
370.33 days in CON suckered plant. In case of March-April planting, 19 days early flowering was found in TC BARI Kola-3 than CON suckered plant. Also, TC BARI Kola-4 produced $50 \%$ flowering within 343.33 days which was 22 days earlier than CON suckered plant. Both the varieties produced 15 days early flowering in MarchApril planting. Plants derived from CON sucker produced flower in different times where TC plants produced within 7-10 days from starting. Remarkable variation was found in days to harvest due to the combined effect of season and planting materials (Table 1). Maximum 482.33 days was needed for harvesting CON suckered BARI Kola-3 while 471.67 days was needed in TC plants at September-October planting. But in March-April planting, 449 days needed for TC plants where 474.33 days needed in CON suckered plants of BARI Kola-3 (Table 1). At least 22 days early harvesting was found in March-April planting than September-October planting in BARI Kola-3. Days required for harvesting were ranged from 434.33 to 450 . Sixteen days early harvest was done in TC BARI Kola-4 than CON suckered BARI Kola-4 in September-October planting. In case of March-April planting, TC BARI Kola-4 was harvested 20 days earlier than CON suckered plants. Early harvesting was found in March-April planting in both the varieties than September-October planting. These results are in accordance with the findings of Faisal et al., 1998. The combined effects of season and planting materials had significant influence on yield and yield contributing characters (Table 1 \& Figure 3). TC plants had significant effect on number of fingers per hand in BARI Kola-3 than CON suckered plants. Maximum number of fingers per hand 15.45 was recorded in TC plant followed by CON suckered plant (14.63). Similar trends were also found in case of individual finger weight $(\mathrm{g})$, finger size $\left(\mathrm{cm}^{2}\right)$, weight of individual bunch $(\mathrm{g})$ and yield of bunch $(\mathrm{kg})$ at September-October plantation (Table 1). TC BARI Kola-4 also produced higher number of fingers per hand (15.45), number of finger per bunch (164.85), number of hands per bunch (10.67), followed by CON suckered plants 14.63, 150.73 and 10.30, respectively at September-October planting. Similar tread was also found in individual finger weight, finger size, weight of individual hand, weight of individual bunch and bunch yield at both of September-October and March-April planting (Table 1). Wide variation was found in respect of yield due to the effect of season and planting materials. The highest $55.89 \mathrm{t} \mathrm{ha}^{-1}$ bunch yield was found from TC BARI Kola-4 followed by $45.67 \mathrm{t} \mathrm{ha}^{-1}$ in TC BARI Kola-3 in March-April planting (Figure 3). In case of September-October planting, TC BARI Kola-3 and BARI Kola4 produced 49.67 and $44.05 \mathrm{t} \mathrm{ha}^{-1}$, respectively which was $12.34 \%$ and $9.35 \%$ higher over CON suckered plant. Hilly peoples usually planted banana during the month of March-April. During this period raining starts at hilly areas and soil contains moisture which helps to better growth and development of plants.

During the period of September-December, hilly areas suffer from drought and water scarcity. Due to the absent of rain water plant cannot get abundant moisture. As a result, growth and development of plants hampered and production reduced. However, TC BARI Kola-3 produced $49.67 \mathrm{t} \mathrm{ha}^{-1}$ followed by TC BARI Kola-4 
Table 1. Effect of planting season and propagating materials on the growth and yield of BARI Kola-3 and BARI Kola-4 at hilly areas

\begin{tabular}{|c|c|c|c|c|c|c|c|c|c|c|c|c|c|}
\hline \multirow[t]{2}{*}{ Treatments } & \multirow{2}{*}{$\begin{array}{l}\text { Plant } \\
\text { height } \\
(\mathrm{cm})\end{array}$} & \multirow{2}{*}{$\begin{array}{l}\text { Base girth } \\
(\mathrm{cm})\end{array}$} & \multirow{2}{*}{$\begin{array}{c}\text { Total no. } \\
\text { of leaves } \\
\text { at harvest } \\
\text { per plant }\end{array}$} & \multirow{2}{*}{$\begin{array}{c}\text { Days to } \\
50 \% \\
\text { flowering }\end{array}$} & \multirow{2}{*}{$\begin{array}{l}\text { Days to } \\
\text { harvest }\end{array}$} & \multirow{2}{*}{$\begin{array}{c}\text { No. of } \\
\text { hands per } \\
\text { bunch }\end{array}$} & \multirow{2}{*}{$\begin{array}{c}\text { No. of } \\
\text { fingers per } \\
\text { bunch }\end{array}$} & \multirow{2}{*}{$\begin{array}{c}\text { No. of } \\
\text { fingers per } \\
\text { hand }\end{array}$} & \multirow{2}{*}{$\begin{array}{l}\text { Individual } \\
\text { finger } \\
\text { weight }(\mathrm{g})\end{array}$} & \multicolumn{2}{|c|}{ Finger size $\left(\mathrm{cm}^{2}\right)$} & \multirow{2}{*}{\begin{tabular}{|c|}
$\begin{array}{l}\text { Wt. of } \\
\text { indi. hand } \\
(\mathrm{kg})\end{array}$ \\
\end{tabular}} & \multirow{2}{*}{$\begin{array}{c}\text { Indi. } \\
\text { bunch } \\
\text { weight } \\
\text { (kg) }\end{array}$} \\
\hline & & & & & & & & & & Length & Breadth & & \\
\hline $\mathrm{S}_{1} \mathrm{M}_{1}$ & $344.33 \mathrm{bc}$ & $82.11 \mathrm{~b}$ & $23.40 \mathrm{a}$ & $375.00 \mathrm{bc}$ & $471.67 \mathrm{ab}$ & 10.67 a-d & $164.85 \mathrm{ab}$ & $15.45 \mathrm{a}$ & $105.00 \mathrm{~b}$ & $13.33 \mathrm{c}$ & $3.88 \mathrm{~b}$ & $1.54 \mathrm{c}$ & $17.62 \mathrm{c}$ \\
\hline $\mathrm{S}_{1} \mathrm{M}_{2}$ & $337.67 \mathrm{bc}$ & $74.89 \mathrm{~d}$ & $22.89 \mathrm{ab}$ & $392.00 \mathrm{a}$ & $482.33 \mathrm{ab}$ & $10.30 \mathrm{~cd}$ & $150.73 \mathrm{~b}$ & $14.63 \mathrm{~b}$ & $88.00 \mathrm{c}$ & $12.11 \mathrm{e}$ & $3.50 \mathrm{c}$ & $1.36 \mathrm{e}$ & $15.68 \mathrm{~d}$ \\
\hline $\mathrm{S}_{1} \mathrm{M}_{3}$ & $335.00 \mathrm{c}$ & $70.11 \mathrm{e}$ & $22.66 \mathrm{~b}$ & $359.33 \mathrm{e}$ & $434.33 \mathrm{~b}$ & $11.43 \mathrm{a}$ & $161.28 \mathrm{ab}$ & $14.11 \mathrm{bc}$ & $112.33 \mathrm{~b}$ & $15.07 \mathrm{a}$ & $3.96 \mathrm{ab}$ & $1.53 \mathrm{~cd}$ & $18.27 \mathrm{c}$ \\
\hline $\mathrm{S}_{1} \mathrm{M}_{4}$ & $318.00 \mathrm{~d}$ & $65.11 \mathrm{f}$ & $22.21 b c$ & $370.33 \mathrm{~cd}$ & $450.00 \mathrm{~b}$ & $10.97 \mathrm{a}-\mathrm{c}$ & $149.54 \mathrm{~b}$ & $13.63 \mathrm{c}$ & $85.33 \mathrm{c}$ & $11.82 \mathrm{f}$ & $3.32 \mathrm{c}$ & $1.20 \mathrm{f}$ & $15.07 \mathrm{~d}$ \\
\hline $\mathrm{S}_{2} \mathrm{M}_{1}$ & $356.33 \mathrm{a}$ & $85.04 \mathrm{a}$ & $22.85 \mathrm{ab}$ & $361.00 \mathrm{e}$ & $449.33 \mathrm{~b}$ & $11.17 \mathrm{ab}$ & $177.71 \mathrm{a}$ & $16.06 \mathrm{a}$ & $109.71 \mathrm{~b}$ & $13.86 \mathrm{~b}$ & $3.96 \mathrm{ab}$ & $1.77 \mathrm{~b}$ & $19.87 \mathrm{~b}$ \\
\hline $\mathrm{S}_{2} \mathrm{M}_{2}$ & $347.00 \mathrm{ab}$ & $77.83 \mathrm{c}$ & $22.61 \mathrm{~b}$ & $380.00 \mathrm{~b}$ & $474.33 \mathrm{a}$ & $10.08 \mathrm{~d}$ & $162.73 \mathrm{ab}$ & $16.17 \mathrm{a}$ & $93.14 \mathrm{c}$ & $12.35 \mathrm{~d}$ & $3.49 \mathrm{c}$ & $1.49 \mathrm{~cd}$ & $18.17 \mathrm{c}$ \\
\hline $\mathrm{S}_{2} \mathrm{M}_{3}$ & $338.67 \mathrm{bc}$ & $73.58 \mathrm{~d}$ & $21.77 \mathrm{c}$ & $343.33 \mathrm{e}$ & $417.67 \mathrm{~b}$ & $11.13 \mathrm{ab}$ & $171.62 \mathrm{a}$ & $16.15 \mathrm{a}$ & $124.44 \mathrm{a}$ & $15.11 \mathrm{a}$ & $4.10 \mathrm{a}$ & $1.99 \mathrm{a}$ & $22.36 \mathrm{a}$ \\
\hline $\mathrm{S}_{2} \mathrm{M}_{4}$ & $319.67 \mathrm{~d}$ & $70.45 \mathrm{e}$ & $21.87 \mathrm{c}$ & $365.33 \mathrm{de}$ & $437.67 \mathrm{~b}$ & $10.57 \mathrm{~b}-\mathrm{d}$ & $163.17 \mathrm{ab}$ & $16.00 \mathrm{a}$ & $91.47 \mathrm{c}$ & 12.01 ef & $3.40 \mathrm{c}$ & $1.42 \mathrm{de}$ & $17.42 \mathrm{c}$ \\
\hline $\begin{array}{c}\text { Level of } \\
\text { significance }\end{array}$ & $* *$ & $* *$ & $*$ & ** & ** & $* *$ & $* *$ & $*$ & $* *$ & $* *$ & $* *$ & $* *$ & $* *$ \\
\hline $\mathrm{CV} \%$ & 6.65 & 7.19 & 6.85 & 6.31 & 8.98 & 4.25 & 5.96 & 7.93 & 4.81 & 7.01 & 6.11 & 4.14 & 7.63 \\
\hline
\end{tabular}

$\mathrm{S}_{1}=$ September-October planting, $\mathrm{S}_{2}=$ March-April planting, $\mathrm{M}_{1}=\mathrm{TC}$ BARI Kola-3, $\mathrm{M}_{2}=\mathrm{CON}$ sucker of BARI Kola-3, $\mathrm{M}_{3}=$ TC BARI Kola-4, $\mathrm{M}_{4}=$ CON sucker of BARI Kola-4.

Means bearing same letters are not significantly different at $1 \%$ level. 
(44.05 $\mathrm{t} \mathrm{ha}^{-1}$ ) in September-October planting which was $9.36 \%$ and $12.34 \%$ over yield on CON suckered plants of BARI Kola-3 and BARI Kola-4, respectively (Figure 3). Rahman et al. (2002) found 9.34\% higher yield in TC Amrithsagar banana over plants raised from CON sucker. Faisal et al. (1998) also found higher yield, better growth and development in TC plants against CON suckered plant of banana cv. Champa.

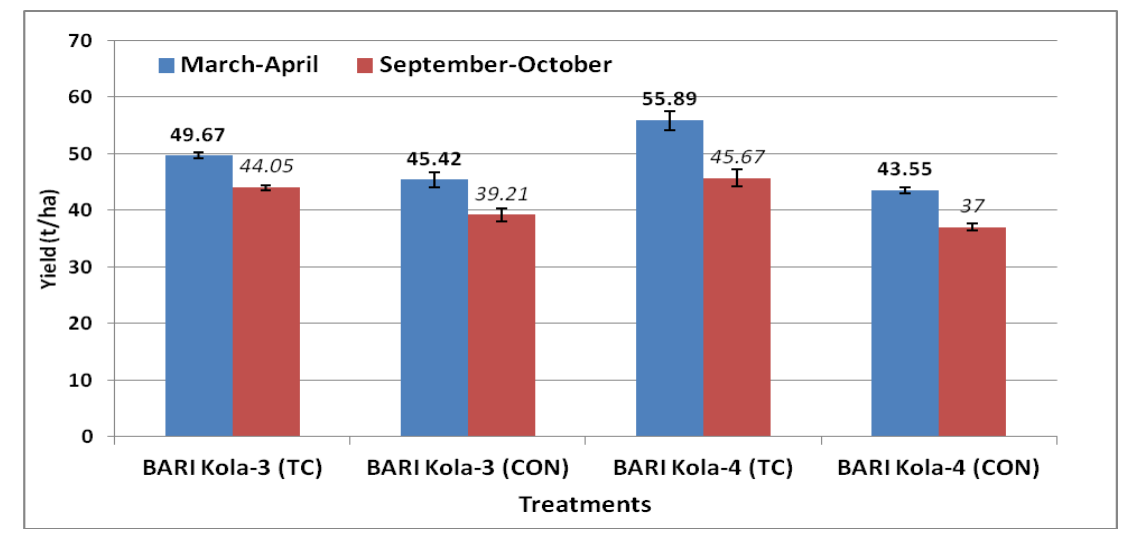

Figure 3. Yield at September-October and March-April plantation

\section{CONCLUSION}

From the above results, MS medium supplemented with $3 \mathrm{mg} 1^{-1}$ and $5 \mathrm{mg} 1^{-1}$ BAP was found suitable for in vitro multiple shoot production from the shoot tip of BARI Kola-3 and BARI Kola-4, respectively. $1 / 2$ MS medium supplemented with 0.5 mg $1^{-1}$ IBA has been found suitable for in vitro root production for both the varieties. BARI Kola-4 showed the better performance for commercial cultivation at hill valleys than BARI Kola-3. March-April planting season is better than the SeptemberOctober planting at hilly areas due to available rain water. In every case, TC plants showed the better performance than the plants derived from CON sucker.

\section{ACKNOWLEDGEMENT}

Thanks to KGF-BARC to provide fund for conducting this research through standardization of protocol, in vitro production of BARI Kola-3 \& BARI Kola-4 plantlets and their validation in hilly areas project. Cordial thanks to DAE personnel to help and cooperate to execute this project in very remote areas of Khagrachai and Rangamati hill districts.

\section{REFERENCES}

Akhond, M.A.Y. and Bhuiyan. S.A. 2001. Tissue culture-er kolar charar chash padhati (in Bengali), Biotechnology Division, BARI, Gazipur-1701. p. 4 
Anonymous. 2010. Baseline survey report on Banana, Agricultural Research Station, Raikhali, Rangamati Hill District. Pp. 35-43

Anonymus. 2013-14. Area and production of Banana. Year book of agricultural statistics of Bangladesh. Bangladesh bureau of statistics, Ministry of planning, Government of the Peoples' Republic of Bangladesh, Dhaka. p.150

Faisal, S.M., Hoque, M.A. and Quasem, A.1998. Field performance of in vitro plantlets against normal sucker of banana cv Champa. Plant Tissue Culture, 8(2):125-129

Gomez, K.A. and Gomez. A.A. 1984. Statistical Procedures for Agricultural Research $\left(2^{\text {nd }}\right.$ Edn.). John Willy and Sons, New York. Pp. 207-215

Khanam, D., Khatun, M.M., Molla, M.M.H., Khan, A.S.M.M.R. and Al-Amin, M. 2007. Micropropagation of tuberose using different auxin and cytokinins. Journal of Molecular biology and biotechnology, 5(1\&2): 12-14

Khanam, D., Molla, M .M. H., Firoz, Z.A. and Rashid, A.S. M.H. 2014. Standardization of protocol, in vitro production of BARI Kola-3 \& BARI Kola-4 plantlets and their validation in hilly areas (Project completion report, Project ID: C-7.12). CGP phase-1, KGF Project ID C-7.12 Pp. 55

Khatun, M.M., Khanam, D., Molla, M.M.H. and Al-Amin, M. 2003. In vitro propagation of banana through shoot tip culture. Progress Agric, 1\&2: 1-5

Khatun, M.M., Khanam, D., Molla, M.M.H., Malek, M.A. and Al-Amin, M. 2006. Micropropagation in Phaius tankervillae orchids. Bangladesh Journal of Agricultural Research, 31(4): 545-550

Molla, M. M. H., Khanam, D., Khatun, M. M., Al- Amin, M. and Malek, M.A. 2004. In vitro rooting and ex-vitro plantlet establishment of BARI Banana-1 (Musa sp.) as influenced by different concentration of IBA (Indol 3-Butyric Acid), Asian Journal of Plant Sciences, 3(2): 145-150, 2004

Murashige, T. and Skoog, F. 1962. A revised medium for rapid growth and bioassays with tobacco tissue culture. Plant Physiology, 15:473-497

Rahman, M.M.S., Hoque, M.A., Islam, M.S., Hossain, T.M.S. and Rahman, M.M. 2002. Effect of suckers and desuckering techniques on yield and quality of Banana. Bangladesh Journal of Science \& Technology, 4(2):291-297

Saha, M. G. 2010. Studies on genetic diversity of bananas grown in Bangladesh, Ph.D Thesis, Department of Horticulture, Bangladesh Agricultural University, Mymensingh. P. 250

Sanavy, S.A.M.M. and Moeini, M.J. 2003. Effect of different hormone combinations and planting beds on growth of singlenodes and plantlets resulted from potato meristem culture. Plant Tissue Culture, 13(2): 145-150

Uddin, M.S., Kamal, M.S. and Molla, M.M.H. 2000. Hill farming system and resource utilization in the hill tracts - A baseline survey. Prokash Printing and Packaging, 23/F1, Free school street, Panthapath, Dhaka-1205, Pp.64 